\title{
The Constitutionality of State Attempts to Regulate Foreign Investment
}

\author{
Cheryl Tate
}

Foreign direct investment (FDI) ${ }^{1}$ in the United States increased sevenfold in the past decade, ${ }^{2}$ creating one of the most hotly debated political issues of the late 1980's. Some see increased foreign investment as a threat to our economic independence, political sovereignty, and national security. ${ }^{3}$ Free trade proponents emphasize the positive aspects of FDI, which include creation of jobs, introduction of new technologies and management techniques, and consumer benefits through increased competition. ${ }^{4}$ They also cite the United States international commitments to free trade advo-

1. There are two types of foreign investment, "direct" (meaning ownership of $10 \%$ or more of the equity in a United States business or real estate interest) and "portfolio" or "passive" (including all other investments such as United States bank accounts, bonds, and security interests of less than $10 \%$ in a United States corporation). Richardson, United States Policy Toward Foreign Investment: We Can't Haz'e It Both Ways, 4 AM. U.J. Int's L. \& Pol'y 281, 285 (1989).

2. FDI soared from $\$ 54.5$ billion on January 1,1980 to $\$ 390.1$ billion on December $31,1989$. Foreign Int'rstment Tops $\$ 390$ Billion, Rising 616 Percent Over the Decade, Daily Rep. for Executives (BNA) No. 50, at A-19 (Mar. 14, 1990). The United States now ranks as the foremost host nation for FDI. Fry, Foreign Direct Investment in the United States: The Differing Perspectives of Washington, D.C. and the State Capitals, 1989 B.Y.U. L. REv. 373, 373. While FDI occurs for many "logical business reasons" including general attractiveness of United States markets, id. at 378-79, the recent surge in FDI activity is attributable in part to the depreciation of the dollar, making United States assets cheaper to buy. Id. at 379-80.

3. See Foreign Investment in the United States: Hearing Before the Subcomm. on International Economic Policy and Trade of the House Comm. on Foreign Affairs, 100th Cong., 2d Sess. 122-24, 128-29 (Sept. 22, 1988) [hereinafter Sept. 1988 Hearing] (statement of Professor Susan Tolchin) (expressing concerns about dependence on foreign capital, political influence of foreign investors and impact of FDI on national security). This concern is not unwarranted. Although foreign nationals are prohibited from making direct contributions to Federal and state campaigns, 2 U.S.C. $\S 441$ e (1988), foreign-owned United States corporations are not prohibited from forming political action committees (PAC's) through which contributions can be made. Durbin, Foreign Participation in Federal Eleclions: A Legal Analysis, Cong. Res. Serv. Rep. No. 87-554A, at 4 (June 28, 1987); see also M. Tolchin \& S. Tolchin, Buying Into America: How Foreign Money Is Changing the Face OF OUR NATION 110-28 (1988) (documenting example of foreign lobbyists' influence in repeal of California state tax); $f f$. N. Glickman \& D. Woodward, The New Competitors: How Foreign Investors ARe Changing the U.S. Economy 271-73 (1989) (foreign PAC political power is cause for concern but only operates within established rules of American politics).

4. See Richardson, supra note 1, at 292-95; see also Sept. 1988 Hearing, supra note 3, at 224-25 (statement of professor Edward M. Graham) (describing long-run benefits of FDI for workers and consumers). But see O'Connell, The Engine That Couldn't: Despite Appearances, Foreign Investment in the United States Doesn't Do Much to Power Job Creation or Drive the Economy, Los Angeles Times, Dec. 4, 1988, $\S 4$ (Business), at 3, col. 1 . 
cacy, ${ }^{5}$ as well as the danger of retaliation by our trade partners should the United States impose any investment barriers. ${ }^{8}$

The skyrocketing level of FDI, particularly the increased Japanese presence, ${ }^{7}$ has stirred up a legislative bee-hive of activity reminiscent of that surrounding the "Arab takeover" threat of the 1970's. ${ }^{8}$ Recently, Federal and state law-makers have proposed legislation, largely centering on the need for greater information on FDI ${ }^{9}$ to respond to this perceived threat. Meanwhile, to boost their local economies, states continue to offer financial incentives to foreign corporations, blurring the distinction between local and national economic priorities. ${ }^{10}$

This Note focuses on state attempts to regulate FDI. While important issues arise as to the international legality of Federal foreign investment legislation, ${ }^{11}$ this Note examines solely the possible constitutional challenges to state FDI regulatory proposals. ${ }^{12}$ Part I briefly describes the

5. The United States is one of the leading proponents of the reduction of artificial trade barriers and is currently participating in the Uruguay Round of multilateral negotiations under the General Agreement on Tariffs and Trade (GATT), Oct. 30, 1947, 61 Stat. A7 (parts 5 \& 6), T.I.A.S. No. 1700,55 U.N.T.S. 194, which established a body of rules promoting open and fair trade. Bilateral treaty commitments also require the United States to accord "national treatment" to foreign companies-treatment no less favorable than that granted to domestic enterprises. See, e.g., Convention of Establishment, Nov. 25, 1959, United States-France, 11 U.S.T. 2398, T.I.A.S. No. 4625 (requiring equal treatment under law for foreign and domestic corporations). Critics feel it is inconsistent for the United States to negotiate for more liberal investment policies internationally while moving domestically to monitor FDI. See Sept. 1988 Hearing, supra note 3, at 7 (statement of Robert Ortner, Under Secretary for Economic Affairs, Dept. of Commerce); id. at 233 (statement of professor Edward M. Graham).

6. See Richardson, supra note 1 , at 282 .

7. Although Britain has larger total United States holdings than Japan, see Foreign Intestments Top U.S. Holdings Abroad, Washington Post, at F1, col. 4 (Mar. 14, 1990), fears center on the Japanese "takeover" of United States industries and technology. See, e.g., The Proper Response to Japan's Influence, Bus. WK., July 11, 1988, at 112, 112 (expressing concern that Japan, "an economic adversary in a way that no other country is," is "manipulat[ing] our levers of power").

8. See Note, U.S. Regulation of Foreign Direct Investment: Current Developments and the Congressional Response, 15 VA. J. INT'L L. 611 (1975) (describing legislative response to increased investment by OPEC nations).

9. Federal legislation has been proposed to address other areas of concern about FDI as well. Sce infra notes 35-43 and accompanying text (describing current Federal bills).

10. See infra notes $52-53$ and accompanying text.

11. For a discussion of the legality of Federal FDI measures under international obligations, see, e.g., Note, The Rising Tide of Reverse Flow: Would a Legislative Breakwater Violate U.S. Treaty Commitments?, 72 Mich. L. REv. 551 (1974).

12. This Note will consider only constitutional challenges under the dormant commerce clause and Federal foreign affairs powers, although other constitutional attacks on state FDI regulation are possible. For example, if state regulations contravene United States GATT or bilateral treaty commitments, they are void under the supremacy clause of the Constitution, which provides that all Federal laws including treaties "shall be the supreme Law of the Land." U.S. ConsT. art. VI, cl. 2. For a discussion of limitations imposed upon state regulatory powers by United States international obligations, see, e.g., Jackson, The General Agreement on Tariffs and Trade in United States Domestic Law, 66 MiCH. L. REv. 249 (1967). A preemption challenge may also invalidate state regulations that conflict with Federal FDI laws, or that frustrate accomplishment of general congressional objectives in regulating FDI. See Fidelity Fed. Sav. \& Loan Ass'n v. de la Cuesta, 458 U.S. 141, $152-53$ (1982) (describing preemption standards). Preemption analysis focuses on congressional intent to ban state regulation as evidenced by enactment of laws in a particular field, while a dormant commerce clause challenge examines whether inherent Federal powers and an overriding Federal interest in uniform regulation preclude state regulation, even absent affirmative exercise of congressional powers. 
current foreign investment situation, the existing Federal legislation on FDI, and recent congressional and state proposals. Part II examines the constitutional infirmity of proposed state FDI legislation under the dormant commerce clause. Part III argues that state regulation of FDI would infringe upon the exclusive Federal foreign affairs power. The Note argues that in an increasingly globalized economy, where financial transactions occur at the push of a button and corporate structures stretch beyond national boundaries, ${ }^{13}$ the necessary response to the complex challenges of foreign investment must be a unified national policy. The Note concludes that courts should invoke the dormant commerce clause and the Federal foreign affairs power to invalidate state proposals that restrict FDI. These constitutional restraints on state furtherance of purely local interests assure national uniformity in the foreign relations sphere.

\section{Foreign Direct Investment in the United States}

The United States has historically maintained an open-door policy towards foreign investment. ${ }^{14}$ This policy has theoretical roots in freemarket economic theory, ${ }^{15}$ and until World War I had its practical roots in the need to finance the industrialization and expansion of a developing economy..$^{16}$ But the realities of the global marketplace have called into question the continuing vitality of the liberal trade theory assumption of perfect competition, ${ }^{17}$ and the practical need for foreign investment capital

Ser Rothschild, A Proposed "Tonic" with Florida Lime to Celebrate Our New Federalism: How to Dial Whith the "Headache of Preemption", 38 U. Miamr L. Rev. 829, 840 (1984). The Supreme Court has described the relationship between preemption and pure commerce clause analysis as "the relationship between legislative and judicial enforcement of the Commerce Clause." Arkansas Elec. Coop. Corp. v. Arkansas Pub. Serv. Comm'n, 461 U.S. 375, 382 n.6 (1983). Equal protection and due process challenges to state FDI regulation are also possible, since corporations are considered "persons" for purposes of most constitutional protections. See, e.g., Russian Volunteer Fleet v. United States, 282 U.S. 481 (1931) (corporations entitled to safeguards of Fifth Amendment takings and due process clauses); Minneapolis \& St. L. Ry. v. Beckwith, 129 U.S. 26 (1889) (Fourteenth Amendment due process clause applies to corporations); Santa Clara County v. Southern Pac. R.R., 118 U.S. 394 (1886) (corporations enjoy protection of Fourteenth Amendment equal protection clause).

13. See generally Longworth, Now the Wars Are Economic: Technology's Reach is Eroding Natwnal Sntertgnty, Chicago Tribune, Apr. 23, 1989, § 1, at 1, col. 3 (describing increasing complexities as world market becomes more integrated).

14. Ser President's Message to the Congress Transmitting the 1990 Economic Report, 26 Weekly Comp. Pres. Doc. 180, 183 (Feb. 6, 1990) (statement by President Bush expressing continued commitment to free, competitive markets both domestically and abroad); Statement by the President on International Investment Policy, 19 Weekly Comp. Pres. Doc. 1214, 1214 (Sept. 9, 1983) [hereinafter Reagan Statement] (statement by President Reagan welcoming FDI and opposing government intervention that impedes investment flows).

15. "[T]he fundamental premise of our policy [is] that foreign investment flows which respond to private market forces will lead to more efficient international production . . . " Reagan Statement, supra note 14, at 1214 .

16. Sep generally M. Wilkins, The History of Foreign Investment IN THE UNITED STATES To 1914 (1989) (describing history of role of foreign investment in United States prior to World War I).

17. The assumption of perfect competition postulates that without the distortions of government subsidization or other interference, only the most efficient firms will survive. But in the modern reality of global competition, certain foreign firms are advantaged by, among other factors, home government 
has shifted from that of spurring the growth of a young, developing nation to financing the debt of a developed but overextended economy. ${ }^{18}$

\section{A. Current Federal Restrictions on FDI}

In keeping with its general open trade and investment philosophy, the Federal government places few restrictions on FDI. Most restraints are in specific sectors of the economy, primarily where policy makers have identified a national security interest in keeping an industry out of foreign control. ${ }^{19}$ In addition, the Exon-Florio provision ${ }^{20}$ gives the President or his designee ${ }^{21}$ the power to investigate and block foreign takeovers of domestic corporations that implicate national security. But this may be an ineffective palliative for many concerns about foreign penetration of key domestic industries, since the executive branch historically has been a strong advocate of an open investment policy ${ }^{22}$ and in the past nas been reluctant to reject foreign investment even on national security grounds. ${ }^{23}$

subsidization (e.g., low-interest loans or tax incentives), restrictions on foreign investment inflows, and protection of the home market. See S. Gordon \& F. Lees, Foreign Multinational Investaient in the United States: Struggle for Industrial Supremacy 6-9 (1986).

18. Foreign capital is now directed largely toward financing our astronomical budget deficit. Richardson, supra note 1 , at 295-98. By augmenting a chronically low domestic savings level, the inflow of foreign capital has permitted continued economic growth and relatively low interest rates to coexist with the large budget deficit. See Giordano, Foreign Financing of the Federal Budget Deficit: Myths and Realities, in International Capital Markets: New Directions 113, 123 (S. Kaushik ed. 1989).

19. Seitzinger, Foreign Inzestment in the United States: Major Federal Restrictions, Cong. RES. SERv. Rep. No. 89-376A, at 12 (Apr. 7, 1989). Thus, there are substantive prohibitions on foreign ownership of United States registered vessels, domestic air carriers, mass communications media, mining interests, and nuclear power facilities. There are also limitations on alien participation in defense contracting. $I d$. at $12-26$.

20. 50 U.S.C.A. app. $\$ 2170$ (West Supp. 1989) (added to Defense Production Act of 1950, 50 U.S.C. app. $\$ \$ 2061-2169$ (1982 \& Supp. V 1987) by Omnibus Trade and Competitiveness Act of 1988, Pub. L. No. 100-418, § 5021, 102 Stat. 1107, 1425 (1989)).

21. By executive order, Exec. Order No. 12,661, § 3-201, 3 G.F.R. 618, 620 (1988), the President delegated his investigative authority to the Committee on Foreign Investment in the United States (CFIUS). CFIUS, a sub-Cabinet level interagency commission, reviews transactions and makes recommendations to the President, who then decides whether to take action. See Foreign Inz'estment in the U.S.: Hearing on S. 289 and S. 856 Before the Senate Comm. on Commerce, Science, and Transportation, 101st Cong., 1st Sess. 59 (July 11, 1989) [hereinafter July 1989 Hearing] (statement of Michael Darby, Under Secretary for Economic Affairs, Dept. of Commerce).

22. See N. Glickman \& D. Woodward, supra note 3, at 256-57 (citing examples of past administrations' adherence to free trade policy). But the executive branch is not necessarily monolithic in its free trade policy views; some agencies or administration officials may advocate a more limited policy than the official executive position. Cf. Bush, Citing Security Law, Voids Sale of Aviation Concern to China, N.Y. Times, Feb. 3, 1990, \& 1, at 1, col. 5, 9, col. 2 [hereinafter Bush Voids Sale] (some administration officials, including national security advisor, urged President not to void sale).

23. See N. Glickman \& D. WoODWARD, supra note 3, at 265-69 (discussing confused executive response to Kuwaiti firm's takeover of United States petroleum company and inconsistent executive invocation of "national security" rationale generally). But see Bush Voids Sale, supra note 22, at 1, col. 5. President Bush, in his first use of Exon-Florio, issued an executive order requiring a Chinese government-owned firm to divest its acquisition of a United States aircraft parts manufacturer. His action was criticized as a politically-motivated use of a law designed to protect national security. Id. at 1, col. 5. Furthermore, the President may have exceeded his statutory authority since Exon-Florio states only that the President may "suspend or prohibit any acquisition . . proposed or pending." 50 U.S.C.A. app. $\$ 2170$ (c) (emphasis added). The statute does not explicitly authorize unilateral 
Other Federal measures require registration of foreign-held United States interests for data-gathering purposes. The International Investment and Trade in Services Survey Act (IITSSA) ${ }^{24}$ requires the President to collect data and conduct studies on foreign direct and portfolio investment. ${ }^{25}$ Information compiled under IITSSA is closely guarded; only aggregate data is released to Congress, other executive agencies, and the public. ${ }^{28}$ States are not authorized to receive raw data collected under IITSSA, spurring some to propose their own collection schemes. ${ }^{27}$ The other disclosure statute is the Agricultural Foreign Investment Disclosure Act of 1978 (AFIDA), ${ }^{28}$ which requires registration of foreign interests in agricultural land.

A number of other agencies collect and analyze FDI data, including the Census Bureau. ${ }^{29}$ In addition, Federal securities law requires both domestic and foreign individuals and firms who acquire over a five percent interest in any United States publicly-held corporation to report their interests to the Securities and Exchange Commission. ${ }^{30}$

Presidential action in the case of already completed transactions, but states that the President may "direct the Attorney General to seek appropriate relief, including divestment relief, in the district courts." Id.

24. 22 U.S.C. $\$ \$ 3101-3108(1988)$.

25. The President delegated responsibility for FDI study to the Department of Commerce, see Exec. Order No. 11,961, 3 C.F.R. 86 (1978), reprinted in 22 U.S.C. $\$ 3101$ at 778-79 (1988), whose Bureau of Economic Analysis (BEA) collects information from foreign investors through quarterly, annual, and five-year "benchmark" surveys. See 15 C.F.R. $\$ 806.15$ (h), (i), (j)(2) (1989). Under IITSSA, a "foreign person," defined as an individual or entity resident outside the United States or subject to the jurisdiction of another country, 22 U.S.C. $\$ 3102(3)$, (5) (1988), who acquires or establishes a direct interest of $10 \%$ or more in a United States enterprise must report to the BEA ownership information, the cost of acquisition, and selected financial and operating data on the United States entity. Failure to report triggers civil and criminal penalties. Id. $\S 3105(\mathrm{a})-(\mathrm{c})(1988)(\$ 10,000$ civil fine for failure to submit information; $\$ 10,000$ criminal fine, or one year imprisonment, for willful failure to report). See generally July 1989 Hearing, supra note 21, at 57-58 (statement of Michael Darby, Under Secretary for Economic Affairs, Dept. of Commerce) (describing in detail BEA data collection procedures). Data from BEA surveys are published in aggregate form in the Surrey of Current Business. Id.

26. II. $\$ 3104$ (c) (access to individualized company reports strictly limited; release of information to other than authorized recipients prohibited if it would identify supplier of information); id. $\S$ $3104(\mathrm{~d})$ (civil penalty for violation of $\$ 3104(\mathrm{c})$ ). As a result of its confidentiality policy, the BEA will not release data even in aggregate form in any sector where one or two foreign investors dominate, since that would tend to disclose information about a specific owner. See Jackson, Foreign Direct Incestment in the United States: Data Collection, Disclosure, and Effects, Cong. Res. Serv. Rep. No. $88-79 \mathrm{E}$, at 11 (Jan. 25,1988 ).

27. Sere infra note 58 and accompanying text.

28. 7 U.S.C. $\$ \$ 3501-3508$ (1988). As under IITSSA, analysis of aggregate data is reported to Congress and the President. Id. $\$ 3504$. But under AFIDA, reports filed by individual investors are also available for public inspection, $i d$. $\$ 3506$, and copies of the reports are sent directly to the states where the particular agricultural holding is located. $I d$. $\$ 3505$. This process may reflect congressional recognition that agricultural assets profoundly implicate national sovereignty concerns and warrant closer monitoring.

29. See N. GLICKMaN \& D. Woonward, supra note 3 , at 309.

30. Ser 15 U.S.C. $\$ 78 \mathrm{~m}(\mathrm{~d})$ (1988). But the SEC compiles the reported information only alphabetically by company or individual name, not by nationality, making research of foreign ownership levels difficult. See Federal Collection of Infornation on Foreign Investment in the U.S.: Hearing Btfore the Stmate Comm. on Commerce, Science, and Transportation, 100th Cong., 2d Sess. 12 (Mar. 24, 1988) [hereinafter Mar. 1988 Hearing] (statement of Rep. John Bryant). 
Yet in spite of the volume and varied sources of FDI information, the United States may well be suffering from a "data gap" ${ }^{\text {"1 } 1}$ that prevents formulation of a coherent policy. Critics assail the uncoordinated efforts among data-collecting agencies, the inaccessibility of information on particular foreign investors, and the incompleteness and inaccuracy of much published aggregate data. ${ }^{32}$ There are persuasive reasons for revamping present data collection methods, ${ }^{33}$ but the United States must carefully balance the need for better information with its international commitments and budgetary constraints. ${ }^{34}$

\section{B. Proposed Federal FDI Legislation}

Several recent Federal proposals have addressed the need for an improved data analysis system, some by allowing for greater informationsharing among Federal agencies. ${ }^{35} \mathrm{~A}$ more controversial proposal is the Foreign Ownership Disclosure Act of $1989,{ }^{36}$ also known as the Bryant bill, which would impose new reporting and disclosure requirements on foreign investors. ${ }^{37}$ Registration information would be compiled in individualized form and made available to a wider range of agencies (including state agencies) and individuals than under any current data collection scheme. $^{38}$

Other Federal proposals address national security ${ }^{39}$ and tax ${ }^{40}$ concerns,

31. Sep N. Glickman \& D. Woodward, supra note 3, at 303.

32. See Mar. 1988 Hearing, supra note 30, at 10-15 (statement of Rep. John Bryant); N. Glickman \& D. Woodward, supra note 3, at 303-08.

33. See Sept. 1988 Hearing, supra note 3, at 125-27 (statement by professor Susan Tolchin) (arguing that many economic and political factors implicated by foreign investment require closer analysis based on improved data including, inter alia, technology transfer and foreign government ownership of United States government securities).

34. See supra notes $5,18$.

35. See, e.g., H.R. 4060, 101st Cong., 2d Sess. (1990) (introduced by Rep. Philip Sharp) (authorizing greater information-sharing among BEA, Census, General Accounting Office (GAO) and President); S. 856, 101st Cong., 1st Sess., reprinted in July 1989 Hearing, supra note 21, at 20 (similar to H.R. 4060, but does not provide for GAO access to BEA data). The Bush administration has proposed its own more limited bill. See Administration Drafting Legislation to Improve Foreign Int'estment Data, Daily Rep. for Executives (BNA) No. 52, at A-17 (Mar. 16, 1990) [hereinafter Administration Drafing Legislation] (proposing information-sharing only between Census and BEA).

36. H.R. 5, 101st Cong., 1st Sess., 135 Cong. Rec. E5-E6 (daily ed. Jan. 3, 1989); see also S. 289, 101 st Cong., 1st Sess., 135 Cong. Rec. S856-57 (daily ed. Jan. 31, 1989) (mirror Senate bill).

37. Foreign investors who hold or acquire an interest of greater than five percent in a United States property would be required to register with the Secretary of Commerce. H.R. 5, supra note 36, at $\S 2(\mathrm{a})-(\mathrm{b})$. Stiff civil and criminal penalties would be assessed for violations of the Act. Id. $\S 2(\mathrm{~g})$ (\$10,000 civil fine for late registration); id. $\S 2(\mathrm{~h})(1)-(2)(\$ 10,000 \mathrm{criminal}$ fine, and/or one year imprisonment for willful failure to register; forfeiture of United States interest if convicted of "pattern or practice" of criminal violations under Act).

38. Id. $\$ 2(l)(1)-(2)$ (access granted to congressional committees, "authorized" GAO officials and employees, one designated agency in each state, and "persons performing qualified research" as determined by Secretary of Commerce).

39. See S. 1379, 101st Cong. 1st Sess., 135 Cong. Rec. S8602 (daily ed. July 24, 1989)(amending and reauthorizing Defense Production Act, including provision to lower standard for presidential blocking of foreign takeovers under Exon-Florio).

40. See H.R. 4308, 101st Cong., 2d Sess. (1990) (introduced by Rep. Daniel Rostenkowski) (expanding Internal Revenue Service authority to examine foreign company's records and imposing tax 
and one bill expands registration requirements for United States agents of foreign principals. ${ }^{41}$ Several proposals are concerned with reciprocity of investment opportunities. ${ }^{42}$ One bill proposes a sector-specific restriction on foreign investment. ${ }^{43}$

The Bryant disclosure bill in particular has engendered a storm of criticism. Its detractors argue that it is discriminatory, excessively burdensome, and allows virtual public disclosure of corporate proprietary information, ${ }^{44}$ which would chill foreign investment at a time when foreign capital is most needed to finance the budget and trade deficits. ${ }^{45}$ The Bryant proposal has also provoked international responses, including hints of retaliation from other nations. The British government sent notice of its disapproval of the bill to the Congress, decrying its "burdensome and discriminatory nature," and warning that "[i]t will be more difficult for the British government to resist such requirements in the United Kingdom and in the European Community if the United States-the major source of foreign direct investment in Europe-were to introduce them."46

Whatever the fate of any one particular bill, the continuing spate of Federal proposals suggests that the FDI issue is here to stay. ${ }^{47}$ The issue

on disposition of stock in domestic corporations held by foreign shareholders with $10 \%$ interest).

41. See S. 176, 101st Cong., 1st Sess. (1989) (introduced by Sen. John Heinz) (strengthening registration and reporting requirements for United States persons engaged in broadly-defined political activities for foreign principals); see also H.R. 1333, 101st Cong., 1st Sess. (1989) (introduced by Rep. Timothy Johnson) (identical House bill).

42. See S. 2028, 101st Cong., 2d Sess. (1990) (introduced by Sen. Donald Riegle) (empowering Federal banking agencies to prohibit acquisitions by foreign banks if Secretary of Treasury determines foreign bank's home country denies national treatment to United States banks); H.R. 3699, 101st Cong., 1st Sess. (1989) (introduced by Rep. Thomas Campbell) (requiring United States Trade Representative to take reciprocal action against foreign country that denies national treatment to United States investment).

43. Sep H.R. 2643, 101st Cong., 1st Sess. (1989) (introduced by Rep. Edward Markey) (restricting foreign ownership of cable television stations).

44. Among other information, foreign holders of a $5 \%$ or greater interest in a United States entity must disclose the market value of the asset. H.R. 5, supra note 36 , at $\S 2$ (c)(1)-(6). In addition, foreign holders of a $25 \%$ or greater interest must disclose more detailed financial and operating information, including balance sheets and income statements, and sales and asset figures. Id. § 2(d)(2)(A)-(C). Confidentiality becomes more difficult the more widely information is disseminated, and public disclosure could disadvantage foreign investors by giving competitors or potential takeover suitors access to proprietary information. Such requirements may create incentives for respondents to distort or omit information and thus could actually lead to less accurate data on FDI. See July 1989 Hearing, supra note 21, at 56 (statement of Michael Darby, Under Secretary for Economic Affairs, Dept. of Commerce).

45. See Mar. 1988 Hearing, supra note 30, at 43 (statement of Robert Ortner, Under Secretary for Economic Affairs, Dept. of Commerce); id. at 87-90 (statement of Elliot Richardson on behalf of Association of Foreign Investors in America). But sponsors of the bill believe it is a necessary response to the perceived flaws in present data collection methods, imposes no greater burdens than current SEC filing requirements, and is far less restrictive than the FDI monitoring policies of other industrialized nations. See Mar. 1988 Hearing, supra note 30, at 4-6 (statement of Sen. Thomas Harkin); id. at 10-15 (statement of Rep. John Bryant). For a comparison of the Group of Seven industrialized nations' investment policies, see Richardson, supra note 1 , at 300-07.

46. Letter from British Ambassador Sir Antony Acland to Hon. Norman F. Lent (Mar. 15, 1988), reprinted in 134 CoNG. REC. E859 (daily ed. Mar. 29, 1988).

47. Recent polls reveal popular support for some FDI restrictions. See Sept. 1988 Hearing, supra note 3, at 131 (statement of professor Susan Tolchin) (citing survey that shows $78 \%$ of those polled favor restricting FDI). The Bryant legislation, in particular, has endured for years in Congress and 
will continue to challenge national law-makers until a coherent policy on FDI is achieved, a goal that is increasingly urgent for United States competitiveness in the global marketplace. ${ }^{48}$

\section{State Responses to FDI}

State policy-makers are also attuned to both the opportunities and challenges presented by FDI. Due in part to President Reagan's "New Federalism," 4 with its emphasis on state initiatives in many areas of domestic policy, states in the last decade have had to assert greater control over their own economic destinies.

Furthermore, the internationalization of industries and the globalization of markets has affected local communities as foreign imports compete with local industries, ${ }^{50}$ and as capital flows more freely in and out of state jurisdictions raising the specter of job displacement. ${ }^{51}$ States have increasingly gone abroad to attract needed capital and to maximize local employment as more United States firms locate in other countries. ${ }^{\mathbf{5 2}}$ Such state initiatives raise problems at the national policy-making level..$^{53}$

But concurrently with active promotional campaigns to attract FDI, some states have begun to take a harder look at FDI's impact, proposing a variety of legislative measures ${ }^{54}$ that potentially have even greater national

has been considered in a number of variations, further attesting to the lasting vitality of the issue. See Jackson, Registering Foreign Investment: Proposed Legislation, Cong. Res. SERv. Issue Brief No. 89,092 (July 11, 1989) (detailing history of Bryant bill).

48. See S. Gordon \& F. LeEs, supra note 17, at 1-27 (1986) (concluding United States industries are disadvantaged by lack of Federal policy on FDI).

49. "The key . . . is that the States and localities make the critical choices. . . . A major sorting out of Federal, State, and local responsibilities will occur, and the Federal presence and intervention ... will gradually diminish." President's Message to the Congress Transmitting the Fiscal Year 1983 Budget, 18 Weekly Comp. Pres. Doc. 129, 141 (Feb. 8, 1982); see also President's Message to Congress Transmitting the Fiscal Year 1991 Budget, 26 WeEkLY Comp. Pres. Doc. 139, 139 (Jan. 29, 1990) (President Bush reiterating Federal policy of promoting initiatives at the state and local level).

50. N. Glickman \& D. WoOdwaRd, supra note 3, at 225.

51. "Though capital is mobile, workers, their families, and their communities are not. When GE Motors shifts production to Mexico or Malaysia, it leaves behind unemployed workers-some of whom, if Honda or Hoechst move in, can be re-employed." Id. at 276.

52. In 1989, 41 states and territories sent delegations abroad largely to seek foreign investment, National Governors Ass'n, Governors' Travel Abroad 'Opens the Door' to Increased Exports, Foreign Investments, Tourism, and Other Ventures 1 (April 2, 1990) (news release), and 43 states had permanent trade offices abroad (figure calculated from statistics printed id. at appendix on state overseas representation). For a discussion of the reasons for states' pursuit of foreign investment, see Fry, supra note 2 , at $376-78$.

53. As one analyst has concluded : "A]ttempts by most of the State governments to attract foreign investments blur the boundary between international and domestic economic interests and could complicate the efforts of the Federal Government to negotiate with foreign governments to reduce incentives for and restrictions on foreign direct investments." Jackson, Foreign Direct Investment in the United States, Cong. Res. Serv. Issue Brief No. 87,226, at 1 (July 11, 1989). But see S. Gordon \& F. LEEs, supra note 17 , at 6 (state incentives only influence locational pattern of FDI, not overall amount or composition of inflow).

54. Legislators in California, Florida, Hawaii, Illinois, Indiana, Maine, Massachusetts, Oregon, and Texas have introduced bills in the past year that FDI interest groups have labelled "discriminatory against foreign investment." Foreign Inzestors Concerned over Investment Bills in Nine States, 
policy implications. The uncertain future of these state bills does not diminish the importance of the issue, for recent state measures evince growing concern over FDI. ${ }^{\text {ss }}$

As at the national level, many state measures focus on the need for greater information about FDI in order to adequately assess its impact on local economies. ${ }^{56}$ It is possible to identify several general categories of state FDI measures. Some state bills merely authorize general FDI information-gathering and study of currently available data; ${ }^{57}$ others impose new registration and disclosure requirements on foreign investors. ${ }^{58}$ One bill erects a sectoral bar to FDI ${ }^{59}$ and one is concerned with reciprocity of investment opportunities. ${ }^{60}$ Several of the bills impose civil and criminal penalties for violations of reporting provisions. ${ }^{61}$

States perceive significant local economic interests in monitoring FDI.

INSIDE U.S. TRADE, June 16, 1989, at 10. See infra notes 57-60, 62 (listing bills).

55. Most state proposals died in the last legislative sessions. Telephone interviews with California, Florida, Hawaii, Illinois, Indiana, Maine, Massachusetts, Oregon, and Texas state legislative information offices (Aug. 16, 1989) (notes on file with author). But given that 1990 is an election year, identical or similar bills are likely to be reintroduced as legislators respond to increasing public concern over foreign investment levels. Interview with Bradley Larschan, secretary of the Association for International Investment (AFII), in Washington, D.C. (March 22, 1990) (notes on file with author). Two bills have been enacted. See Haw. S. 1898, 15th Leg., 1st Sess. (1989) (codified at Haw. REv. Stat. \$ 226-103 (Supp. 1989); Ind. S. 89, 106th Gen. Ass., 1st Sess. (1989) (codified at IND. CodE ANN. \$23-2-3.1-2, -3,-4, -5, -5.5 (Burns 1989)).

56. As one advocate of increased registration and disclosure explained: "We are not presuming to suggest at what point foreign ownership and control becomes undesirable-or intolerable. Before state Iegislatures can make such a judgment, they need to have unquestioned data on the extent of foreign ownership or control." July 1989 Hearing, supra note 21, at 255 (statement of Robert Denman, Director, National Farmers Union).

57. Sep, e.g., Cal. S. 2320, 1988-89 Reg. Sess. (requiring state agency to publish annual report on size and industry concentration of FDI); Me. H.R. 1012, 114th Leg., 1st Reg. Sess. (1989) (creating commission to study impact of FDI); Mass. S. 116, 107th Gen. Ct., 1st Ann. Sess. (1989) (establishing commission to investigate and study FDI); Or. S. 1131, 65th Leg., 1988 Reg. Sess. (requiring state agency to collect, compile, interpret, and disseminate to public information on FDI in real property).

58. See, e.g., Cal. S. 1303, 1988-89 Reg. Sess. (foreign investors must file annual registration statements disclosing identity and interests in real property and businesses); Fla. H.R. 1179, 21st Reg. Sess. (1989) (foreign corporations must file application with Florida Department of State and publish intent to do business in local newspaper); Ill. H.R. 0566, 86th Gen. Ass., 1st Sess. (1989) (Foreign Ownership Disclosure Act) (establishing comprehensive registration and annual reporting requirements for foreign corporations similar to Federal Bryant disclosure provisions); Ind. S. 89, 106th Gen. Ass., 1st Sess. (1989) (codified at IND. CODE ANN. § 23-2-3.1-2, -3, -4, -5, -5.5 (Burns 1989)) (requiring inter alia that foreign offeror in corporate takeover action file statement with state securities commissioner disclosing financial sources to be used in takeover and proposed consummation date of takeover; copy of statement must be delivered to target company); Tex. H.R. 2663, 71st Reg. Sess. (1989) (requiring partially or wholly foreign government-owned entity to file statement disclosing interests of greater than $10 \%$ in Texas petroleum-related business and imposing screening procedure for foreign acquisition of petroleum-related business); see also Tex. H.R. 741, 71st Reg. Sess. (1989) (requiring Texas corporations to file statement disclosing any foreign ownership of shares).

59. See Tex. H.R. 250, 71st Reg. Sess. (1988) (prohibiting foreign government or governmentowned entity from acquiring interest in minerals located in Texas).

60. Sep Ill. H.R. 0618, 86th Gen. Ass., 1st Sess. (1989) (prohibiting grant of state incentives to foreign corporations unless their domiciliary nation offers reciprocal incentives).

61. See, e.g., Cal. S. 1303, supra note 58, $\$ 12267$ ( $\$ 10,000$ civil penalty for failure to file); Ill. H.R. 0566, supra note 58, $\$ \S 10-11$ ( $\$ 10,000$ civil fine for each week registration is late; $\$ 10,000$ criminal fine for willful failure to register). 
The statement of purpose in one enacted Hawaii bill ${ }^{62}$ stresses the "fundamental right" of a community to "shape its own destiny."63 Although the bill simply purports to make more explicit the state priorities for investment "irrespective of country of origin,"64 its preamble clearly expresses the vaguely defined but strongly felt fears of many local communities concerning the economic impact of outside investment. ${ }^{65}$ Hawaii also submitted a-resolution to Congress in support of the Bryant disclosure bill, expressing further concerns about the potentially destructive impact of the free flow of capital. ${ }^{66}$ Besides seeking to minimize the economic impact of foreign competition, states may also be concerned about potential foreign corporate influence in the local political sphere. ${ }^{67}$

Given the states' current lack of access to Federally compiled raw FDI data and the unlikelihood of passage of the Bryant legislation ${ }^{68}$ (the only Federal bill proposing information-sharing with state agencies) ${ }^{\mathbf{6 9}}$ the states will most likely continue to move to fill the perceived regulatory gap. ${ }^{\mathbf{7 0}}$ Such state action raises serious constitutional issues.

62. Haw. S. 1898, 15th Leg., 1st Sess. (1989) (codified at Haw. Rev. STAt. $§ 226-103$ (Supp. 1989)).

63. Id. $\S 1$, at 2 (uncodified preamble).

64. Id.

65.

Investment by outside sources becomes an issue. . . when it is perceived that negative impacts outweigh the community needs. These negative impacts are almost always expressed in subjective terms such as: loss of local control; a sense of diminishing opportunities; fear that social and economic benefits are accurring at a faster rate to nonresidents than residents; and examples of scarce resources falling into the hands and control of "outsiders."

The free flow of capital can be a productive force in a community. . . . However, the free flow of capital left purely to the response of market forces is also capable of engendering destructive forces. In order for a community to achieve maximum benefits and minimize negative results, the free flow of capital must be shaped by the explicit economic goals of the community as well as its cultural and social objectives.

Id. $\$ 1$, at $1-2$.

66. See Haw. H.R. Res. 235, 15th Leg., 1989 Reg. Sess., reprinted in 135 Cong. Rec. S6723 (daily ed. June 15, 1989). The Maine legislation expresses similar concerns over the potential "undesirable costs of creating stronger foreign competitors who compete with producers in the State," and the bill aims to design a "strategy to encourage and direct compatible and desirable types of foreign investment and to discourage undesirable investmerit." Me. H.R. 1012, supra note 57, Statement of Fact, at 3.

67. See supra note 3 (describing potential political influence of foreign-sponsored PAC's).

68. The senior trade counsel to the Senate Commerce Committee, which has jurisdiction over the Bryant bill, predicted that the proposal probably will not pass due to its controversial nature and lack of support in committee. See Administration Drafting Legislation, supra note 35, at A-17. Should the bill pass Congress, Bush administration officials have promised to recommend a presidential veto. See Letter from Secretary of Treasury Nicholas F. Brady to Congress (Feb. 15, 1989).

69. See supra note 36 ; supra note 38 and accompanying text.

70. Furthermore, in the past, state and municipal authorities have frequently responded to national problems with their own measures. See, e.g., T. Franck \& M. Glennon, Foreign RelaTIONS AND National. SEcurity Law 711-22 (1987) (recounting ban of Soviet citizens from municipal recreational facilities because of alleged Soviet spying activities); Note, State and Local AntiSouth Africa Action as an Intrusion upon the Federal Pouler in Foreign Affairs, 72 VA. L. REv. 813 (1986) (describing state economic measures directed against South Africa). For a discussion of the questionable constitutionality of such action under the foreign affairs power, see infra text accompanying notes $123-47$. 


\section{Constitutionality of State Regulation of Foreign Investment Under the Dormant Commerce Clause}

The commerce clause is one of the most sweeping constitutional limitations on the exercise of state power. Although the commerce clause is an affirmative grant of power to Congress, ${ }^{71}$ courts interpret its dormant powers or "negative implications"72 to strike down state acts that interfere with the free flow of interstate and foreign commerce. ${ }^{73}$

The judicially developed dormant commerce clause doctrine had one of its earliest and most important expressions in Cooley v. Board of Wardens, ${ }^{74}$ wherein the Supreme Court upheld a Pennsylvania statute that required ships in interstate and foreign commerce to use local pilots when navigating in state waters. The Court distinguished between those areas of commerce that "are in their nature national, or admit only of one uniform system, or plan of regulation, [and] may justly be said to be of such a nature as to require exclusive legislation by Congress"75 and those areas where "local necessities" demand diverse regulation.

Thus, not all state action affecting commerce is barred; states retain broad power to legislate to protect the health, safety, and welfare of their inhabitants. ${ }^{77}$ In order to accommodate both legitimate local needs and the overriding requirement of freedom of interstate trade, courts must appraise the competing state and Federal interests. In conducting this analysis, the Supreme Court has distinguished between "outright protectionism and more indirect burdens on the free flow of trade." legislation that discriminates on its face against out-of-state actors is subject to a "virtually per se rule of invalidity," wh wile legislation that impacts equally upon both interstate and local business may survive constitutional scrutiny. ${ }^{\mathbf{8 0}}$

The Supreme Court described the balancing test used on facially neutral state regulations in Pike v. Bruce Church, Inc. ${ }^{81}$ The Court there enjoined an Arizona official from ordering a local fruit-grower to pack its high-quality fruit locally in the interest of promoting the reputation of

71. "Congress shall have Power . . . [t]o regulate Commerce with foreign Nations, and among the several States...."U.S. ConST. art. I, $\$ 8$, cls. 1,3 .

72. L. Tribe, American Constitutional Law § 6-2, at 403 (2d ed. 1988).

73. "[T]he Commerce Clause was not merely an authorization to Congress to enact laws . . . but by its own force created an area of trade free from interference by the States. . . . [T]he Commerce Clause even without implementing legislation by Congress is a limitation upon the power of the States." Freeman v. Hewit, 329 U.S. 249, 252 (1946).

74. 53 U.S. (12 How.) 299 (1851).

75. In. at 319 .

76. Id.

77. Set H.P. Hood \& Sons, Inc. v. Du Mond, 336 U.S. 525, 531-32 (1949). In Brown v. Maryland, 25 U.S. (12 Wheat.) 419, 443-44 (1827), this power was christened the state "police power."

78. Lewis v. BT Inv. Managers, 447 U.S. 27, 36 (1980).

79. City of Philadelphia v. New Jersey, 437 U.S. 617, 624 (1978).

80. Let'2s, 447 U.S. at 36.

81. 397 U.S. 137 (1970). 
Arizona products. The Court held that where a state statute regulates evenhandedly to effectuate a legitimate local public interest with only incidental effects on interstate commerce, it will be upheld unless the burdens imposed on commerce are clearly excessive in relation to the local benefits. The permissibility of the burden depends on the nature of the local interest involved, and on whether it could be advanced as well with a lesser impact on interstate commerce. ${ }^{82}$ Although the state action in Pike advanced an admittedly legitimate local interest, it imposed a clearly excessive burden on commerce by requiring business operations to be performed in Arizona that could more efficiently be performed out-of-state. ${ }^{83}$

The Pike balancing analysis may well be weighted more heavily against state FDI laws since they regulate foreign rather than interstate commerce. Recent Supreme Court cases assert that state infringements on foreign commerce require "more extensive constitutional inquiry" fringements on interstate commerce since "there is evidence that the Founders intended the scope of the foreign commerce power to be the greater." 85

\section{A. Economic Protectionism and Per Se Invalidity}

Proposed state FDI statutes that facially discriminate against foreign investors ${ }^{88}$ warrant the strictest scrutiny ${ }^{87}$ Similar statutes have been criticized as " 'parochial' in the sense that [they] overtly prevent[] foreign enterprises from competing in local markets," 88 and have been invalidated under the per se invalidity test. In City of Philadelphia v. New Jersey, ${ }^{89}$ the Court made clear that states may not seek to solve their local problems by discriminatorily burdening "articles of commerce coming from outside the State unless there is some reason, apart from their origin, to treat

82. Id. at 142.

83. Id. at 145 .

84. Japan Line v. County of Los Angeles, 441 U.S. 434, 446 (1979).

85. Id. at 448 . There are distinguishable policies behind the grants of the foreign and interstate commerce powers; "the latter was intended to secure equality and freedom in commercial intercourse as between the States, . . . while the former clothed Congress with that power over international commerce, pertaining to a sovereign nation in its intercourse with foreign nations, and subject . . . to no implied or reserved power in the States." The Lottery Case, 188 U.S. 321, 373 (1903) (Fuller, C.J., dissenting) (emphasis added); see also Reeves, Inc. v. Stake, 447 U.S. 429,438 n.9 (1980) (state restrictions burdening foreign commerce subject to more rigorous scrutiny). These decisions seem to have discredited the Court's earlier dictum that the two powers are coextensive. See The License Cases, 46 U.S. (5 How.) 504, 578 (1847) ("The power to regulate commerce among the several States is granted to Congress in the same clause, and by the same words, as the power to regulate commerce with foreign nations, and is coextensive with it.").

86. See bills cited supra notes 58-60. Other bills that merely authorize study of FDI based on already-existing data and do not impose new reporting burdens solely on foreign corporations appear constitutionally sound. See bills cited supra note 57.

87. See Hughes v. Oklahoma, 441 U.S. 322, 337 (1979) (facial discrimination alone may be fatal defect; at minimum, facially discriminatory statutes invoke strictest scrutiny of alleged legitimate local purpose and absence of less burdensome means).

88. Leuris, 447 U.S. at 39.

89. 437 U.S. 617 (1978). 
them differently."90 New Jersey had attempted to extend the life of its landfills and minimize the need to convert scarce open lands into new disposal sites by prohibiting out-of-state garbage to enter local landfills. But the state's admittedly legitimate environmental and health concerns did not justify restrictions which discriminated against out-of-state waste; the Court held that "the evil of protectionism can reside in legislative means as well as legislative ends." "91

In Lewis v. BT Investment Managers, ${ }^{92}$ the Court similarly criticized the protectionist nature of a Florida state law that prohibited ownership of local investment or trust businesses by out-of-state banks and holding companies. While the Court by-passed the per se rule to hold that disparate treatment of out-of-state enterprises was not justified as an incidental burden necessitated by legitimate local interests, its strong language suggests that the Florida statute could as easily have been stricken as per se invalid. ${ }^{93}$

Although protectionist in nature, most state FDI proposals impose burdens short of the explicit prohibition of foreign participation in state markets evident in City of Philadelphia and Lewis. ${ }^{94}$ It is at least arguable that they may thus survive invalidation under the per se test.

\section{B. Intentional Discrimination}

Many of the state bills betray a clear purpose of protecting local economic interests by means of burdening only participants in foreign commerce. For example, one Texas bill imposes a screening requirement on entities with any amount of foreign government ownership that seek to acquire a petroleum-related business. ${ }^{95}$ Approval depends on an assessment of the "best economic interest of th[e] state." ${ }^{\text {"96 }}$ But domestic corporations may acquire a Texas petroleum-related business without undergoing this process. Such intentional discrimination against commerce places squarely on the state the burden of justifying local benefits and of showing

\footnotetext{
90. Id. at 627 (emphasis added).

91. Id. at 626 .

92. 447 U.S. 27 (1980).

93.

Under the Florida statute, discrimination against affected business organizations is not evenhanded because. . . only companies with principal operations outside Florida are prohibited from operating investment subsidiaries or giving investment advice within the State ... . [The statute] discriminates annong affected business entities according to the extent of their contacts with the local economy ... [and] thus displays a local favoritism or protectionism that significantly alters its Commerce Clause status.

Id. at 42 (emphasis in original) (citations omitted).

94. But spe Tex. H.R. 250, supra note 59 (prohibiting foreign government-owned entities from acquiring interest in Texas minerals).

95. See Tex. 2663, supra note 58, § 3. Presumably, the screening requirement would apply to even those corporations with as little as one percent foreign government ownership. Id. $\$ 1$ (1) (foreign corporation subject to requirement is one "any part of which is owned by a government of a foreign country").

96. Id. \$3.
} 
the unavailability of nondiscriminatory alternatives. ${ }^{97}$ This would prove a difficult burden since the Supreme Court has refused to recognize vague appeals to the interest of local economic control made by states seeking to protect their markets from foreign penetration. ${ }^{98}$

States may indeed need more information about FDI before its true impacts on local economies can be assessed. But it is doubtful that a vague a priori argument of potentially "destructive forces" justify intentionally discriminatory data-gathering techniques or screening procedures that place even minimal burdens on the more strictly guarded zone of foreign commerce.

\section{Legitimacy of State Interests, Rational Relation of Legislation, and Balancing of Burdens}

State regulations that affect commerce will be upheld under Pike if they are rationally related to a legitimate state interest that outweighs any burden imposed upon commerce, and there is no less burdensome way to effectuate the desired goals.

None of the identifiable interests underlying state FDI proposals seem justifiable under the Pike balancing test. State FDI regulations that seek to protect the local economy from potentially negative effects of foreign competition, if not per se void as pure economic protectionism, ${ }^{\mathbf{1 0 0}}$ are invalid since they are not rationally related to the desired ends. There is no evidence that a foreign corporation located in a particular state is any more likely to close down its operations, displace workers, or otherwise threaten the local economy than a domestic counterpart. In fact, foreign investors often buy facilities discarded by United States firms relocating abroad. ${ }^{101}$ Furthermore, the definition of "foreign" in several of the state bills would include many domestically-owned corporations with major operations located abroad. ${ }^{102}$ A more rational and less discriminatory solu-

97. See Hunt v. Washington State Apple Advertising Comm'n, 432 U.S. 333, 353 (1977). The state should bear a heavier burden when it intentionally discriminates against foreign commerce. See supra notes 84-85 and accompanying text.

98.

In almost any Commerce Clause case it would be possible for a State to argue that is has an interest in bolstering local ownership, wealth, or control of business enterprise. Yet these arguments are at odds with the general principle that the Commerce Clause prohibits a State from using its regulatory power to protect its own citizens from outside competition. Lewis, 447 U.S. at $43-44$ (citations omitted).

99. See supra note 65 and accompanying text (describing Hawaii's articulation of threatened local interest).

100. See supra text accompanying notes 86-94.

101. See July 1989 Hearing, supra note 21, at 233 (statement of Richard F. Celeste, Governor of Ohio); see also supra note 51 (describing potential for foreign corporations to re-employ displaced workers).

102. See, e.g., Ill. H.R. 0566, supra note $58, \S 2(f)(2)$ (foreign person includes "any business enterprise that is organized under the laws of a foreign government or which has its principal place of business outside of the United States"); Ind. S. 89, supra note 58, $\$ 5($ b)(1) (codified at IND. CoDE ANN. § 23-2-3.1-5.5(b)(2) (Burns 1989)) (foreign corporation is one "incorporated under a law other 
tion, given that analyzing currently available data may be inadequate, ${ }^{103}$ would be to collect and evaluate data from both foreign and domestic corporations.

FDI proposals also largely fail in their attempts rationally to address potential foreign influence in local politics. A foreign-incorporated or foreign-owned entity does not necessarily espouse the political agenda of its domiciliary nation; corporate goals are predominantly economic rather than political. ${ }^{104}$ At some level of foreign government ownership, though, it would be more rational to presume that the corporation seeks to advance the interests of the foreign nation. But less burdensome alternatives exist for meeting this concern: States could directly regulate foreign lobbying practices or restrict foreign PAC contributions to state campaigns, and thereby avoid discriminating against or burdening foreign commerce at all.

To the extent that state measures attempt to solve more national problems, such as promotion of the United States' general industrial competitiveness or insistance upon international reciprocity of investment incentives, ${ }^{105}$ they infringe upon the proper domain of Congress in regulating affairs with foreign nations. ${ }^{108}$

While asserted state interests are vague, the potential burdens of state FDI regulations are not entirely clear either. Many states' registration requirements impose no greater burdens than those already imposed under IITSSA. ${ }^{107}$ Yet even the cost of duplicitous filings may be impermissibly burdensome where state interests are not demonstrably legitimate. One clearly significant burden is the threat of state-imposed civil and criminal penalties ${ }^{108}$ upon a foreign corporation for nondisclosure or nonregistration when the foreign investor has already complied with Federal requirements.

Cries that any new burdens imposed would "chill foreign investment" or invite retaliation are not unfounded, as the British government's letter to Congress voicing concern over the Bryant proposal attests. ${ }^{109}$ Further-

\footnotetext{
than the law of the United States or any state of the United States").

103. But some states have proposed just this solution to the FDI "threat." See supra note 57 (listing bills authorizing collection and study of currently available FDI data).

104. Sez D. Vagts, Transnational Business Problems 111 (1986). Furthermore, the potentially negative impact of concentrated corporate wealth on the political process is not limited to foreign corporate power, since both foreign and domestic corporations will pursue political strategies in order to advance their economic goals. See Sept. 1988 Hearing, supra note 3, at 139 (statement of professor Norman J. Glickman) (directing attention to possible undue political influence of domestic corporations as well).

105. See, e.g., Ill. H.R. 0618, supra note 60; infra text accompanying note 135.

106. Sit $m f r a$ notes 123-47 and accompanying text (discussing exclusive Federal foreign affairs powers).

107. But see Ill. H.R. 0566, supra note 58 (imposing same detailed requirements as proposed Bryant bill).

108. See supra note 61 (listing state bills that penalize foreign investors for nondisclosure).

109. See supra note 46 and accompanying text.
} 
more, leaving it to the states to enact a hodgepodge of different FDI requirements also creates a significant danger of inconsistency in an area where the nation must present a unified front in its dealings with international commercial partners.

\section{The Need for Uniformity in Regulating Foreign Commerce}

The need for national uniformity is particularly urgent in the regulation of foreign commerce ${ }^{110}$ and transcends the balancing analysis. Thus, the Supreme Court in Japan Line v. County of Los Angeles ${ }^{111}$ struck down a Galifornia property tax on Japanese cargo containers on the grounds that it would prevent the nation from "speaking with one voice"112 in regulating foreign trade. The Court did not invoke any notions of balancing of interests and burdens, but instead stressed the possibility of international dispute and foreign retaliation against United States interests. ${ }^{113}$

The Court has recognized, however, that there may be certain state regulations that "merely [have] foreign resonances"114 that fall short of intrusion into the foreign affairs domain. Thus, the Court in Container Corp. of America v. Franchise Tax Board ${ }^{115}$ upheld a California tax that was imposed on a domestic corporation but included foreign subsidiaries in the calculation of income. The Court found that, since the tax applied directly to a domestic corporation, it created only a slight risk of foreign retaliation, minimal offense to foreign nations, and implicated no other foreign policy concerns. ${ }^{116}$

But in Alcan Aluminum, Ltd. v. Franchise Tax Board, ${ }^{117}$ the Seventh Gircuit criticized the same California tax as applied to domestic subsidiaries of foreign corporations. The court cited the "potential for the . . . tax to penalize foreign ownership of American assets," which distinguished it from more legitimate state regulation that might increase the costs of doing business in a particular state but would equally affect foreign and

110. The question of whether state action violates the dormant foreign commerce clause is closely related to the question of whether such action intrudes upon the foreign affairs power. See, e.g., Container Corp. of America v. Franchise Tax Bd., 463 U.S. 159, 194 (1983) (state tax may impermissibly burden foreign commerce if it implicates foreign policy issues requiring Federal resolution); Bd. of Trustees v. Mayor of Baltimore, $317 \mathrm{Md} .72,138,562$ A.2d 720, 752 (1989) (purpose behind both foreign commerce clause and foreign affairs powers limitations on state regulation is to prevent individual states from adversely affecting relations with foreign countries); see also Note, supra note 70 , at 832 (two doctrines are distinguishable only in that foreign commerce clause challenge to state action is subset of broader foreign affairs power concerns); infra text accompanying notes 123-47 (discussing foreign affairs power limitation on state action).

111. 441 U.S. $434(1979)$.

112. Id. at 453 .

113. Id. at 450 .

114. Container Corp. of America v. Franchise Tax Bd., 463 U.S. 159, 194 (1983).

115. 463 U.S. 159 (1983).

116. Id. at $194-97$.

117. 860 F.2d 688 (7th Cir. 1988). 
domestically-owned enterprises. ${ }^{118}$ The court concluded that the burdening of foreign corporations' decisions to do business through subsidiaries in the state threatened to offend the United States' trading partners and provoke retaliation. ${ }^{119}$

These cases suggest that, if neither per se invalidity nor traditional commerce clause balancing will suffice to strike down discriminatory state FDI regulations, the uniformity doctrine will sound their death knell. Particular state regulations, appropriately drafted, may create mere "resonances" in foreign commercial intercourse if they affect both domestic and foreign entities equally. But most state FDI bills impose requirements likely to disproportionately burden a foreign corporation's decision to conduct business in a particular state ${ }^{120}$ and raise the threat of foreign retaliatory measures.

Some state FDI regulations may impose burdens that only minimally raise a foreign investor's costs of doing business in the state. But when taken together, these state regulations have a serious "potential to disfavor a particular mode of foreign participation"121 in United States markets. Courts have considered the potential aggregate effects of individual activity on interstate commerce to be sufficient to justify congressional action in analogous "active" commerce clause cases ${ }^{122}$ and should also restrain potential aggregate state burdens on foreign commerce in the dormant commerce clause context.

\section{The Constitutionality of State FDI Regulations Under THE Foreign AfFairs Power}

The power of the Federal government over foreign affairs is exclusive and "plenary."123 The sources for this plenary power are largely found in the Constitution, which vests in the national government explicit powers to deal with a vast array of transnational problems. ${ }^{124}$

Whatever the proper distribution of powers among the Federal

118. Id, at 697 .

119. Id.

120. Only Hawaii's economic prioritization bill even purports to regulate domestic and foreign entities evenhandedly. See supra note 62; text accompanying note 64.

121. Alcan, 860 F.2d at 697.

122. See, e.g., Wickard v. Filburn, 317 U.S. 111, 127-28 (1942) (Federal restriction on wheat production to minimize effect of consumption of home-grown wheat on interstate market is justified even though individual farmer's contribution to demand for wheat "may be trivial by itself," because "his contribution, taken together with that of many others . . . is far from trivial").

123. Both legislative and executive foreign affairs powers have been described as "plenary." See, e.g., Buttfield v. Stranahan, 192 U.S. 470, 492-93 (1903) (Congress has "plenary power" over foreign imports); United States v. Curtiss-Wright Export Corp., 299 U.S. 304, 320 (1936) (noting "delicate, plenary and exclusive power" of executive in international relations).

124. Congress is allocated the power to provide for the common defense, to declare war and raise armies, to regulate foreign commerce and maritime activities, to impose duties, and to establish a uniform naturalization law. U.S. CoNST. art. I, $\S 8$. The President is empowered by the Constitution to make treaties and to appoint ambassadors (subject to legislative advice and consent), and to serve as Commander-in-Chief of the armed forces. U.S. CoNST. art. II, $\S 2$, cls. 1, 2. 
branches, ${ }^{125}$ the states clearly are denied major participation in the formulation and execution of foreign policy. The Constitution explicitly prohibits states from entering any "Treaty, Alliance, or Confederation," from imposing import or export duties, from entering any "Agreement or Compact" with foreign powers, and from engaging in war. ${ }^{126}$ Judicial constraints imposed under the dormant commerce clause doctrine, particularly the uniformity principle in the foreign commerce context, have further prevented the states from intruding into the realm of foreign relations. ${ }^{127}$

State infringements into the Federal foreign affairs domain are prohibited even where commerce is not involved. Thus, in Zschernig $v$. Miller, ${ }^{128}$ the Supreme Court invalidated as applied an Oregon statute that conditioned a foreign citizen's right of inheritance on a showing of reciprocal rights granted to United States citizens by the alien's country. ${ }^{129}$ State courts, in searching for reciprocity under these statutes, conducted detailed examinations of foreign state policies, often passing judgment on foreign practices. ${ }^{130}$

The Court in Zschernig did not invalidate such state laws as per se unconstitutional, thus leaving undisturbed its prior decision in Clark $\%$. Allen, ${ }^{\mathbf{1 3 1}}$ which had upheld a similar regulation. The statute in Clark had required only "routine reading of foreign laws."132 But application of the Oregon statute involved "minute inquiries concerning the actual administration of foreign law . . matters which the Constitution entrusts solely to the Federal Government." ${ }^{\text {133 }}$ The Court concluded that such inquiries

125. For a discussion of the Federal distribution of powers in the foreign affairs area, see generally H. Steiner \& D. Vagts, Transnational Legal Problems 152-205 (3d ed. 1986).

126. U.S. Const. art. I, $\$ 10$.

127. See supra note 110 (describing relation between foreign commerce clause and foreign affairs power limitations on state action).

128. 389 U.S. 429 (1968).

129. Such state statutes, commonly called "iron curtain" statutes, operated largely to deny inheritance to residents of communist countries. See generally Comment, Iron Curtain Statules, Communist China, and the Right to Devise, 32 UCLA L. REv. 643 (1985) (discussing constitutional challenges to "iron curtain" statutes).

130. See, e.g., In re Belemecich's Estate, 411 Pa. 506, 192 A.2d 740 (1963) (concluding that Soviet state would confiscate any inheritance sent to one of its citizens).

131. 331 U.S. 503 (1947).

132. Zschernig, 389 U.S. at 433.

133. Id. at 435-36. In Zschernig, the Court determined for itself that the state law impermissibly impacted upon foreign relations, since the executive had not taken the position that the regulation infringed upon the Federal conduct of foreign affairs. Id. at 434. This judicial policing of state infringements upon foreign affairs, even absent any policy directives from the other branches, is consistent with the Supreme Court's emphasis on the "self-executing" nature of the Constitution's limitation on state powers in this exclusive Federal area. See Damrosch, Foreign States and the Constitution, 73 VA. L. Rev. 483, 510 (1987); see also L. TRIBE, supra note 72, \$ 4-6, at 230 (state action, whether or not consistent with current Federal foreign policy, that distorts allocation of Federal-state responsibilities in international relations is unconstitutional infringement upon exclusive Federal domain). 
constitute impermissible intrusion by the state into the field of foreign affairs. ${ }^{134}$

One state FDI proposal seems to entail the kind of state action Zschernig explicitly meant to prohibit. An Illinois bill provides that the state's Department of Commerce shall not offer incentives to foreign firms to locate in the state unless it first determines whether the foreign firm's nation of domicile "offers similar incentives to United States . . . enterprises" and whether that nation "imposes duties or barriers against the importation from the United States of products of the type which the foreign firm proposes to produce in Illinois."135 The determination by a state agency of the existence of trade "barriers" against United States products is a discretionary and subjective assessment. Such forays by a state agency into an area where the Federal government already conducts complex and sensitive determination $\mathbf{s}^{\mathbf{1 3 6}}$ are politically dangerous to United States interests ${ }^{137}$ and constitutionally impermissible.

State measures that do not require detailed inquiries into foreign trade practices are not as clearly within Zschernig's explicit prohibitions. But, adopting a broad reading of Zschernig, the California Supreme Court in Bethlehem Steel Corp. v. Board of Commissioners, ${ }^{138}$ declared unconstitutional a state Buy-American government procurement statute as an "attempt by the state to structure national foreign policy to conform to its own domestic policies." 139 The court warned of the dangers that would develop if Federal policy were to be shaped by the states' differing interpretations and concluded that only the Federal government can determine standards for fair competition with its international trading partners. ${ }^{140}$

Two other state cases have taken a more limited view. In K.S.B. Technical Sales Corp. v. North Jersey District Water Supply Commission, ${ }^{141}$ the New Jersey Supreme Court upheld the state's Buy-American requirement for government purchases, narrowly interpreting Zschernig to prohibit only "refined inquiries into foreign ideologies."142 Since the New Jersey Buy-American act applied "without any discrimination based on

134. Zschernig, 389 U.S. at 432.

135. Ill. H.R. 0618, supra note 60, $\$ 46.4 \mathrm{a}(\mathrm{d})(1)(\mathrm{A}),(\mathrm{B})$.

136. St', $e^{\prime}, g ., 19$ C.F.R. $\$ \$ 207.1-.46$ (1989) (describing complex International Trade Commission (ITC) procedures for determining injury to domestic industry resulting from subsidized exports to United States); $\imath$. $\$ \$ 210.1-.71$ (describing ITC investigation procedures for determining unfair import trade practices).

137. For example, if a state were to deny" an incentive to a Japanese firm because it found that Japan imposes trade "barriers," it could seriously disadvantage the national government's efforts through delicate international negotiations to reduce "emotional trade friction" between the two economic powers. See Japanese Foreign Minister Urges Efforts to End 'Emotional Trade Friction',

Daily Rep. for Executives (BNA) No. 156, at A-3 (Aug. 15, 1989).

138. 276 Cal. App. 2d 221, 80 Cal. Rptr. 800 (1969).

13\%. Id. at 229,80 Cal. Rptr. at 805 .

140. Id. at 226,80 Cal. Rptr. at 803 .

141. 75 N.J. 272, 381 A.2d 774 (1977), appeal dismissed, 435 U.S. 982 (1978).

142. Id at 291,381 A.2d at 784 . 
the ideology of the seller's country," ${ }^{143}$ it was beyond the scope of Zschernig.

In Board of Trustees v. City of Baltimore, ${ }^{144}$ the Maryland Court of Appeals similarly limited Zschernig when it upheld a Baltimore ordinance requiring city pension funds to divest their holdings in companies doing business in South Africa. The court held that the regulation's impact on South Africa (and the resultant threat of retaliation) was "minimal and indirect," 148 and thus did not intrude upon the Federal government's conduct of foreign relations. ${ }^{146}$

State FDI measures intrude upon broader areas of international trade than both the state Buy-American procurement regulations, which limit their scope to government purchase of goods, and the divestment regulations which do not apply to private business transactions. ${ }^{147}$ These greater burdens, combined with the complexity and volatility of modern international investment issues, mandate invalidation of state FDI regulations. Such a result would follow the spirit, if not the letter, of Zschernig.

\section{Conclusion}

International trade issues are increasingly vital to foreign diplomacy. On this matter, and in the realm of international relations generally, the nation must speak with "one voice," not fifty. Given the debate at the national level, it is difficult to identify the "one voice" with which the nation will speak on the issue of foreign investment. Nevertheless, compromise must be hammered out on the Federal level in order to ensure protection of vital national economic needs and respect for international commitments.

Perhaps some resolution that allows for greater coordination of state and Federal efforts in the FDI data collection and analysis process will better serve to satisfy local as well as national needs. Clearly, however, recent state initiatives to take the matter into their own hands seriously threaten the implementation of a unified Federal policy and cannot survive constitutional scrutiny. The dual restraints of the dormant commerce clause and the exclusive Federal foreign affairs power ensure that "[n]o state can rewrite our foreign policy to conform to its own domestic policies."148

143. Id. at 291,381 A.2d at 783 .

144. $317 \mathrm{Md} .72,562$ A.2d 720 (1989), cert. denied, 110 S. Ct. 1167 (1990).

145. Id. at 127,562 A.2d at 746 .

146. Id. at $131,562 \mathrm{~A} .2 \mathrm{~d}$ at 749 .

147. The Maryland Court of Appeals stressed that the divestment ordinance was an attempt by the city to "structure its own financial affairs," and did not curtail the rights of South Africa or any foreign national. Id. at 130, $562 \mathrm{~A} .2 \mathrm{~d}$ at 748 (emphasis added). This distinguished it from invalid state regulations that affected relationships between private individuals and a foreign nation or its citizens. Id.

148. United States v. Pink, 315 U.S. 203, 233 (1942). 